\title{
A DECISÃO HOMOLOGATÓRIA DE AUTOCOMPOSIÇÃO EXTRAJUDICIAL E A COMPETÊNCIA DO JUÍZO: UM ESTUDO SOBRE O ART. 725, VIII DO $\mathrm{CPC} / \mathbf{2 0 1 5}^{1}$
}

\section{THE EXTRAJUDICIAL AGREEMENT HOMOLOGATED BY A COURT DECISION AND THE COMPETENT COURT: A STUDY ABOUT THE ART. 725, VIII OF THE BRAZILIAN CODE OF CIVIL PROCEDURE OF 2015}

Tiago Figueiredo Gonçalves Doutor e Mestre (PUC/SP); Coordenador do Curso de Direito da Universidade Federal do Espírito Santo - UFES; Professor da Universidade Federal do Espírito Santo - UFES (Graduação e Mestrado); Professor (Graduação e PósGraduação) do UNESC e da FUNCAB; Diretor da ESA/ ES; Advogado. Vitória/ES. E-mail: tfgoncalves2@gmail.com

André Silva Martinelli Mestre em Direito Processual (UFES); Especialista em Direito Processual Civil pela Faculdade de Direito de Vitória - FDV; Analista Judiciário do Tribunal Regional do Trabalho da $1^{\mathrm{a}}$ Região. Vitória/ES.

RESUMO: O presente texto procura delimitar o alcance do enunciado contido no art. 725, VIII do CPC/2015 que trata do processamento do pedido de homologação de autocomposição extrajudicial. Busca-se chegar a uma conclusão sobre qual é o órgão jurisdicional competente para homologar autocomposição extrajudicial que contenha algumas cláusulas que, analisadas isoladamente, deveriam ser apreciadas pelo juízo da Justiça Comum e outras de competência do juízo da Justiça do Trabalho.

\footnotetext{
${ }^{1}$ Artigo recebido em 21/12/2020 e aprovado em 29/03/2021.
} 
PAlaVRaS-CHAVE: Código de Processo Civil 2015; Decisão homologatória de autocomposição extrajudicial; Competência; Procedimento de jurisdição voluntária; Ação rescisória.

ABSTRACT: The present text seeks to define the meaning of the statement contained in art. 725, VIII of the Code of Civil Procedure of 2015, which deals with the processing of the application for homologation of extrajudicial agreements. It has the purpose to reach a conclusion on which is the competent court to approve extrajudicial agreement that contains some clauses that, analyzed separately, should be appraised by the courts of law and others that fall within the jurisdiction of the Labor Court.

KEYWORDS: Code of Civil Procedure of 2015; Extrajudicial agreement homologated by a court decision; Jurisdiction; Non-contentious proceedings; Rescisory action.

\section{INTRODUÇÃO}

No início de junho de 2018, o sítio eletrônico do Tribunal Regional do Trabalho da $17^{\text {a }}$ Região noticiou a homologação de acordo em reclamação trabalhista com algumas peculiaridades interessantes. ${ }^{2}$ Segundo o relatado, o reclamante ajuizara reclamação trabalhista em face da reclamada, requerendo o reconhecimento de vínculo empregatício e a condenação ao pagamento das verbas trabalhistas decorrentes da relação de emprego. Ainda conforme essa notícia, uma das questões em discussão neste processo dizia respeito à validade de uma cláusula homologada pelo juízo da Vara de Família, de acordo com a qual o autor, ao se divorciar da filha do dono da reclamada, ${ }^{3}$ renunciava a quaisquer de seus direitos trabalhistas em favor da ré. Na demanda ajuizada perante a Justiça do Trabalho, o reclamante discutia a validade dessa cláusula, alegando que os direitos trabalhistas são irrenunciáveis.

\footnotetext{
2 ACORDO trabalhista entre membros de família encerra processo no TRT-ES. 2018. Disponível em: http://www.trtes.jus.br/principal/comunicacao/noticias/conteudo/1941-acordo-trabalhista-entre-membros-defamilia-encerra-processo-no-trt-es. Acesso em: 16 dez. 2020.

${ }^{3}$ A notícia usa esse termo: "dono da reclamada". Embora saibamos que tecnicamente ele não é o mais adequado, preferimos escrever dessa forma para sermos os mais fiéis possíveis ao conteúdo da reportagem.
} 
Dentre as várias questões que poderiam ser discutidas na análise desse caso, uma em particular nos chamou a atenção: o juízo da Vara de Família possui competência para homologar acordo de divórcio contendo cláusula que trata de renúncia a direitos trabalhistas?

Este questionamento serviu de incentivo para buscarmos a resposta de outra pergunta mais abstrata: um órgão jurisdicional da Justiça Comum, federal ou estadual, é competente para homologar autocomposição feita fora do processo e que disponha, numa de suas cláusulas, de matéria que seja da alçada da Justiça do Trabalho?

A indagação ganha relevância porque a interpretação do texto do art. 725, VIII do $\mathrm{CPC} / 2015^{4-5}$ conduz ao entendimento de que a homologação de autocomposição extrajudicial, de qualquer natureza ou valor, será processada conforme os ditames gerais do procedimento de jurisdição voluntária.

Nesses termos, o alcance da expressão "qualquer natureza" contida no referido dispositivo merece um refinamento. Há uma autorização explícita do legislador para que acordos envolvendo qualquer matéria sejam homologadas por juízo absolutamente incompetente? Caso a resposta seja positiva, como compatibilizar esse dispositivo com a regra da competência absoluta? Se a resposta àquela pergunta for negativa, questiona-se: qual a medida adequada para se impugnar a decisão homologatória de juízo incompetente após o decurso do prazo recursal?

O objeto deste estudo, portanto, é a delimitação do alcance do enunciado contido no art. 725, VIII do CPC/2015, que trata do processamento do pedido de homologação de autocomposição extrajudicial, de qualquer natureza ou valor, conforme as disposições do procedimento de jurisdição voluntária, com o propósito de se chegar a uma conclusão sobre qual é o órgão jurisdicional competente para homologar autocomposição feita fora do processo que contenha cláusulas as quais, analisadas isoladamente, deveriam ser apreciadas pelo juízo da Justiça Comum (Estadual ou Federal) e outras de competência do juízo da Justiça do Trabalho.

\section{BREVE HISTÓRICO DA PREVISÃO DA HOMOLOGAÇÃO PELO} PODER JUDICIÁRIO DE AUTOCOMPOSIÇÃO EXTRAJUDICIAL

\footnotetext{
4 BRASIL. Lei $\mathrm{n}^{\circ}$ 13.105, de 16 de março de 2015. Código de Processo Civil. Disponível em: http://www.planalto.gov.br/ccivil_03/_ato2015-2018/2015/lei/113105.htm. Acesso em: 16 dez. 2020.

${ }^{5}$ Art. 725. Processar-se-á na forma estabelecida nesta Seção o pedido de: [...]; VIII - homologação de autocomposição extrajudicial, de qualquer natureza ou valor.
} 
$\mathrm{O}$ art. 725, VIII do CPC/2015 é uma das novidades do novo diploma processual. Para compreendê-lo, é necessário um breve histórico da legislação anterior que tratava da homologação de autocomposição extrajudicial pelo Poder Judiciário.

A Lei $n^{0} 7.244 / 84^{6}$, chamada de Lei das Pequenas Causas, dispunha sobre a criação e o funcionamento dos Juizados Especiais de Pequenas Causas nos Estados, Distrito Federal e Territórios para processar e julgar causas de reduzido valor econômico. ${ }^{7}$

A competência desses juizados restringia-se a causas que versassem sobre direitos patrimoniais cujo pedido não ultrapassasse o valor máximo de até vinte saláriosmínimos vigentes na data do ajuizamento da demanda. Estavam excluídos da abrangência dessa lei os feitos de natureza alimentar, falimentar, fiscal e de interesse da Fazenda Pública, os relativos a acidentes do trabalho, a resíduos e ao estado e capacidade das pessoas, ainda que de cunho patrimonial. ${ }^{8}$

A parte que optasse por ajuizar a demanda nos Juizados Especiais de Pequenas Causas renunciava ao crédito excedente ao valor superior a vinte salários-mínimos, exceto no caso de conciliação. ${ }^{9}$ Isso significa que era possível a homologação de acordo judicial de valor superior a vinte salários-mínimos, caso as partes convencionassem nesse sentido. A sua execução, porém, independentemente do valor, deveria ser promovida no juízo cível comum, consoante as regras do $\mathrm{CPC} / 73$ (art. 40). ${ }^{10}$

Embora a competência dos Juizados Especiais de Pequenas Causas fosse limitada a processos que tratassem apenas de certos direitos patrimoniais (delimitação da

\footnotetext{
${ }^{6}$ BRASIL. Lei no 7.244 , de 7 de novembro de 1984. Dispõe sobre a criação e o funcionamento do Juizado Especial de Pequenas Causas. Disponível em: http://www.planalto.gov.br/ccivil_03/leis/19801988/17244.htm. Acesso em: 16 dez. 2020.

${ }^{7}$ Art. $1^{\circ}$ - Os Juizados Especiais de Pequenas Causas, órgãos da Justiça ordinária, poderão ser criados nos Estados, no Distrito Federal e nos Territórios, para processo e julgamento, por opção do autor, das causas de reduzido valor econômico.

${ }^{8}$ Art. $3^{\circ}$ - Consideram-se causas de reduzido valor econômico as que versem sobre direitos patrimoniais e decorram de pedido que, à data do ajuizamento, não exceda a 20 (vinte) vezes o salário mínimo vigente no País e tenha por objeto: I - a condenação em dinheiro; II - a condenação à entrega de coisa certa móvel ou ao cumprimento de obrigação de fazer, a cargo de fabricante ou fornecedor de bens e serviços para consumo; III - a desconstituição e a declaração de nulidade de contrato relativo a coisas móveis e semoventes. $\S 1^{\circ}$ - Esta Lei não se aplica às causas de natureza alimentar, falimentar, fiscal e de interesse da Fazenda Pública, nem às relativas a acidentes do trabalho, a resíduos e ao estado e capacidade das pessoas, ainda que de cunho patrimonial.

${ }^{9}$ Art. $4^{\circ}, \S 2^{\circ}$ - A opção pelo procedimento previsto nesta Lei importará em renúncia ao crédito excedente ao limite estabelecido neste artigo, excetuada a hipótese de conciliação.

${ }^{10}$ DINAMARCO, Cândido Rangel. Execução civil. 7. ed. São Paulo: Malheiros, 2000, p. 215.
} 
matéria) com quantia máxima pré-estabelecida pela lei (delimitação do valor), havia previsão normativa no sentido de que o acordo extrajudicial, de qualquer natureza ou valor, poderia ser homologado, no juízo competente, independentemente de termo, valendo a sentença como título executivo judicial. ${ }^{11}$

Disposição semelhante a esta foi repetida na Lei $\mathrm{n}^{\circ} 9.099 / 95^{12}$, que revogou a Lei $n^{0} 7.244 / 84$ e cuidou da criação e regulamentação dos Juizados Especiais Cíveis e Criminais. Os Juizados Especiais Cíveis passaram a ser competentes para processar e julgar causas cujo valor não excedesse a quarenta vezes o salário-mínimo, bem como outras tipicamente delimitadas pelo legislador. ${ }^{13}$

Foram excluídas da competência dos Juizados Especiais Cíveis, segundo o $§ 2^{\circ}$ do art. $3^{\circ}$ da Lei $n^{\circ}$ 9.099/95, “as causas de natureza alimentar, falimentar, fiscal e de interesse da Fazenda Pública, e também as relativas a acidentes de trabalho, a resíduos e ao estado e capacidade das pessoas, ainda que de cunho patrimonial". ${ }^{14}$

Apesar da limitação dos Juizados Especiais Cíveis de processar e julgar ${ }^{15}$ as causas até o valor de quarenta salários-mínimos, a Lei nº 9.099/95 manteve redação idêntica à do art. 55 da lei revogada no que dizia respeito à homologação de acordo extrajudicial. ${ }^{16}$ Ou seja, conservou-se a autorização para que o acordo extrajudicial, de qualquer natureza ou valor, fosse homologado no juízo competente, valendo a sentença como título executivo judicial.

\footnotetext{
${ }^{11}$ Art. 55 - O acordo extrajudicial, de qualquer natureza ou valor, poderá ser homologado, no juízo competente, independentemente de termo, valendo a sentença como título executivo judicial. Parágrafo único - Valerá como título executivo extrajudicial o acordo celebrado pelas partes, por instrumento escrito, referendado pelo órgão competente do Ministério Público.

${ }^{12}$ BRASIL. Lei no 9.099, de 26 de setembro de 1995. Dispõe sobre os Juizados Especiais Cíveis e Criminais e dá outras providências. Disponível em: http://www.planalto.gov.br/ccivil_03/leis/19099.htm. Acesso em: 16 dez. 2020.

${ }^{13}$ Art. $3^{\circ} \mathrm{O}$ Juizado Especial Cível tem competência para conciliação, processo e julgamento das causas cíveis de menor complexidade, assim consideradas: I - as causas cujo valor não exceda a quarenta vezes o salário mínimo; II - as enumeradas no art. 275, inciso II, do Código de Processo Civil; III - a ação de despejo para uso próprio; IV - as ações possessórias sobre bens imóveis de valor não excedente ao fixado no inciso I deste artigo. ${ }^{14}$ Também houve ressalva expressa sobre a incompetência dos Juizados Especiais Cíveis para processar e julgar processos que constassem em um dos polos da demanda o incapaz, o preso, as pessoas jurídicas de direito público, as empresas públicas da União, a massa falida e o insolvente civil, conforme dispõe o art. $8^{\circ}$ da Lei $\mathrm{n}^{\circ}$ 9.099/95.

${ }^{15}$ A Lei no 9.099/95 conferiu aos Juizados Especiais Cíveis competência funcional para também executar as suas sentenças, um dos aspectos o qual se diferenciava da Lei nº 7.244/84, conforme lição de DINAMARCO, Op. Cit., p. 215.

${ }^{16}$ Art. 57. O acordo extrajudicial, de qualquer natureza ou valor, poderá ser homologado, no juízo competente, independentemente de termo, valendo a sentença como título executivo judicial. Parágrafo único. Valerá como título extrajudicial o acordo celebrado pelas partes, por instrumento escrito, referendado pelo órgão competente do Ministério Público.
} 
A existência de norma semelhante no $\mathrm{CPC} / 73^{17}$ somente surgiu a partir de 2005 . A expressa previsão da sentença homologatória de acordo extrajudicial, de qualquer natureza, como título executivo judicial decorreu da inserção do art. 475-N, V, ${ }^{18}$ no CPC/73 por meio da Lei ${ }^{\circ} 11.232 / 2005,{ }^{19-20}$ responsável por uma das muitas reformas sofridas pelo antigo Código, e que tratava especificamente da fase de cumprimento da sentença.

Antes da entrada em vigor da Lei $\mathrm{n}^{\mathrm{o}} 11.232 / 2005$, o art. 584 - que listava os títulos executivos judiciais — tratava, em seu inciso III, ${ }^{21}$ de situação diversa, qual seja, da sentença homologatória de autocomposição judicial proferida em demandas já ajuizadas, ainda que o objeto da conciliação ou da transação não dissesse respeito à questão discutida em juízo. Essa hipótese normativa não autorizava a homologação de autocomposição extrajudicial sem que houvesse um processo judicial em curso. ${ }^{22}$

Tanto é assim que, após a entrada em vigor da Lei $\mathrm{n}^{\circ} 11.232 / 2005$, o CPC/73 erigiu nova hipótese de título executivo judicial formado a partir da sentença homologatória de acordo extrajudicial, de qualquer natureza (art. 475-N, V), em complemento ao já anteriormente existente título executivo judicial constituído a partir de sentença

${ }^{17}$ BRASIL. Lei $\mathrm{n}^{\circ}$ 5.869, de 11 de janeiro de 1973. Institui o Código de Processo Civil. Disponível em: http://www.planalto.gov.br/ccivil_03/leis/15869impressao.htm. Acesso em: 16 dez. 2020.

${ }^{18}$ DIDIER JR., Fredie et al. Curso de Direito Processual Civil: Execução. 6. ed. Salvador: Juspodivm, 2014, vol. 5, p. 170.

${ }^{19}$ BRASIL. Lei n ${ }^{\circ} 11.232$, de 22 de dezembro de 2005. Altera a Lei no 5.869, de 11 de janeiro de 1973 - Código de Processo Civil, para estabelecer a fase de cumprimento das sentenças no processo de conhecimento e revogar dispositivos relativos à execução fundada em título judicial, e dá outras providências. Disponível em: http://www.planalto.gov.br/ccivil_03/_Ato2004-2006/2005/Lei/L11232.htm. Acesso em: 16 dez. 2020.

${ }^{20}$ Art. 475-N. São títulos executivos judiciais: [...]; V - o acordo extrajudicial, de qualquer natureza, homologado judicialmente; [...].

${ }^{21} \mathrm{O}$ art. 584, III sofreu várias reformas ao longo do período de vigência do $\mathrm{CPC} / 73$. A redação originária dispunha que era título executivo judicial "a sentença homologatória de transação, de conciliação ou de laudo arbitral". A Lei $\mathrm{n}^{\circ}$ 8.953/94 modificou o referido texto, para acrescer que a sentença homologatória sobre matéria não posta em juízo também era considerada título executivo judicial (hipótese normativa que, por um lapso, foi excluída pela Lei $\mathrm{n}^{\circ}$ 9.307/1996). Finalmente, em 2001, a Lei $\mathrm{n}^{\circ} 10.358$ alterou novamente o art. 584, III, determinando ser título executivo judicial a sentença homologatória de conciliação ou de transação, ainda que versasse sobre matéria não posta em juízo.

${ }^{22}$ Em sentido diverso, Leonardo Greco entende que o $\mathrm{CPC} / 73$ continha autorização legislativa para homologação pelo juiz de um acordo sobre qualquer matéria, independentemente da pré-existência de um processo judicial ou, ainda que existente, que tratasse de um acordo sobre objeto diverso daquele discutido nos autos, antes mesmo da entrada em vigor da Lei $n^{\circ} 11.232 / 2005$. Em sua obra sobre jurisdição voluntária, ao comentar em 2003 (e, portanto, antes da entrada em vigor do art. 475-N, V no CPC/73) sobre o procedimento de homologação de acordo extrajudicial, Greco afirmou: "Por esse instituto o juiz pode receber o pedido de homologação de um acordo privado sobre qualquer matéria, independentemente da preexistência de uma causa judicial ou, numa causa judicial preexistente, homologar acordo sobre matéria inteiramente estranha ao objeto litigioso". (GRECO, Leonardo. Jurisdição Voluntária Moderna. São Paulo: Dialética, 2003, p. 124). 
homologatória de conciliação ou de transação, ainda que incluísse matéria não posta em juízo (art. 475-N, III).

No que diz respeito ao CPC/2015, o art. 515, III possui redação muito próxima ao antigo art. 475-N, V, do $\mathrm{CPC} / 73$, ao dispor que "a decisão homologatória de autocomposição extrajudicial de qualquer natureza" é título executivo judicial. Houve uma melhoria no texto: substituiu-se "acordo extrajudicial" por "autocomposição extrajudicial" e deixou-se claro que a decisão homologatória é o título executivo judicial, e não o acordo (ou a autocomposição).

O CPC/2015 ainda inovou ao prever, em seu art. 725, VIII, que o pedido de homologação de autocomposição extrajudicial, de qualquer natureza ou valor, será processado conforme as normas gerais do procedimento de jurisdição voluntária.

Esse breve histórico serve para demonstrar de onde veio a redação que hoje consta no CPC/2015, o que ajuda a compreender quais eram as interpretações da doutrina a seu respeito, conforme será abordado mais à frente neste estudo. Tem o escopo de revelar, ainda, que a sentença homologatória de autocomposição extrajudicial passou a ser considerado um título executivo judicial desde a edição da Lei n ${ }^{0} 7.244 / 84$. Com a revogação dessa lei, subsistiu a mesma norma na Lei $\mathrm{n}^{\circ}$ 9.099/95 e, posteriormente, no CPC/73 e agora no $\mathrm{CPC} / 2015$.

Importante destacar que antes do CPC/2015 não existia, previsto de forma expressa na lei, um rito predeterminado para a homologação da autocomposição extrajudicial. Ou seja, havia autorização legal para que o juiz homologasse pedido de autocomposição extrajudicial, mas não constava expressamente na lei qual era o procedimento adequado para que ocorresse essa homologação.

Podemos, assim, expor uma primeira conclusão: o art. 725, VIII do CPC/2015 tem a função de deixar claro para os sujeitos processuais sobre qual é o procedimento para a homologação de autocomposição extrajudicial. Ele atua em complementação ao art. 515, III, do CPC/2015, que trata da formação do título executivo judicial, mas vai além, pois nada impede que se profira decisão homologatória de autocomposição extrajudicial que não resulte em título executivo judicial (como, por exemplo, aquela que trata sobre renúncia de algum direito ou anulação ou desconstituição de um contrato). 
3. A DECISÃO HOMOLOGATÓRIA DE AUTOCOMPOSIÇÃo EXTRAJUDICIAL NO CPC/2015

\subsection{A DIFERENÇA ENTRE O ART. 515, III DO CPC/2015 (DECISÃO} HOMOLOGATÓRIA DE AUTOCOMPOSIÇÃO EXTRAJUDICIAL) E O ART. 515, II, C/C $\S 2^{\circ}$ DO CPC/2015 (DECISÃO HOMOLOGATÓRIA DE AUTOCOMPOSIÇÃO JUDICIAL)

A divisão sistemática dos títulos executivos judiciais decorrentes de autocomposição foi consolidada no CPC/2015, o qual dispôs que são títulos executivos judiciais:

i) a decisão homologatória de autocomposição judicial que poderá envolver sujeito estranho ao processo e versar sobre relação jurídica que não tenha sido deduzida em juízo (art. 515, II c/c $\S 2^{\circ}, \mathrm{CPC} / 2015$ );

ii) a decisão homologatória de autocomposição extrajudicial de qualquer natureza (art. 515, III, CPC/2015).

São duas hipóteses diversas. A norma construída a partir do texto do art. 515, II cumulado com o $\S 2^{\circ}$ do mesmo dispositivo se refere à situação em que há processo judicial em curso e as partes resolvem:

a) pôr fim a todo o litígio ou a parte dele;

b) autocompor-se sobre a lide levada a juízo e/ou outra disputa que ainda não foi judicializada envolvendo os mesmos sujeitos parciais;

c) pôr fim ao conflito envolvendo sujeito estranho ao processo.

Independentemente do caso, a homologação da autocomposição será feita de forma incidental, pois já há processo em curso. ${ }^{23}$

Por outro lado, a decisão homologatória de autocomposição extrajudicial contempla situação em que o conflito ainda não foi levado ao Judiciário. O objeto de demanda judicial, portanto, é a autocomposição já formalizada pelas partes, dependendo

\footnotetext{
${ }^{23}$ Sob a égide do CPC/73, já se apontava a diferença entre as hipóteses previstas no art. 475-N, incisos III e V. Nesse sentido, WAGNER JÚNIOR, Luiz Guilherme da Costa. A sentença homologatória de acordo extrajudicial e sua executoriedade. In: MEDINA, José Miguel Garcia et. al. (coord.). Os poderes do juiz e o controle das decisões judiciais. São Paulo: Revista dos Tribunais, 2008, p. 489.
} 
apenas da homologação pelo juiz para lhes dar maior segurança em futura execução por inadimplemento.

Saliente-se que é possível a já existência de um título executivo extrajudicial, mas os transatores possuírem interesse em torná-lo judicial. ${ }^{24-25} \mathrm{O}$ interesse na homologação

\footnotetext{
${ }^{24}$ Para Daniel Neves, o interesse de agir "é a obtenção de bem da vida que só pode ser conseguido com a atuação jurisdicional, pouco importando nesse caso se já existe um título executivo extrajudicial. E mesmo aqueles que não concordarem com a natureza voluntária da jurisdição, o interesse de agir estará presente em razão do previsto no art. 785 do Novo CPC". (NEVES, Daniel Amorim Assumpção. Manual de direito processual civil - volume único. Salvador: Juspodivm, 2017, p. 1114-1115).

${ }^{25}$ Por relevante, registra-se entendimento firmado, por maioria, pela Terceira Turma do STJ no sentido de não se autorizar a homologação de autocomposição extrajudicial sem que haja uma lide previamente existente e discutida numa ação judicial. $\mathrm{O}$ acórdão encontra-se com a seguinte ementa:

"PROCESSO CIVIL. TRANSAÇÃO EXTRAJUDICIAL. HOMOLOGAÇÃO. LEI 9.099/95. ART. 57. IMPOSSIBILIDADE.
}

1. É imprescindível preservar o escopo da Lei 9.099/95, criada para facilitação de acesso ao Poder Judiciário pelos titulares de direitos relacionados a lides de menor complexidade, com procedimento simplificado e julgamento célere, desafogando-se, com isso, os Tribunais em causas de procedimento ordinário ou sumário. 2. O art. 57 da Lei 9.099/95 tem, em princípio, eficácia transcendente à Lei dos Juizados Especiais. Essa norma, contudo, teria o papel de regular provisoriamente a matéria, até que ela encontrasse regulação específica nos diplomas adequados, a saber, o Código de Processo Civil e o Código Civil.

3. O CPC, nas sucessivas reformas ocorridas desde meados dos anos 90 , vem tendo alterada a redação de seu art. 584, III, de modo a contemplar, com maior ou menor extensão, a possibilidade de homologação de acordos extrajudiciais.

4. Na última alteração a que se sujeitou o código, contudo, incluiu-se o art. 475-N, que em lugar de atribuir eficácia de título executivo judicial à sentença que homologue acordo que verse sobre matéria não posta em juízo, passou a falar em transações que incluam matéria não posta em juízo.

5. Uma transação que inclua matéria não posta em juízo está claramente a exigir que a transação, para ser homologável, tem de se referir a uma lide previamente existente, ainda que tenha conteúdo mais amplo que o dessa lide posta. Assim, a transação para ser homologada teria de ser levada a efeito em uma ação já ajuizada. 6. É necessário romper com a ideia de que todas as lides devem passar pela chancela do Poder Judiciário, ainda que solucionadas extrajudicialmente. Deve-se valorizar a eficácia dos documentos produzidos pelas partes, fortalecendo-se a negociação, sem que seja necessário, sempre e para tudo, uma chancela judicial.

7. A evolução geral do direito, num panorama mundial, caminha nesse sentido. Tanto que há, hoje, na Europa, hipóteses em que ações judiciais somente podem ser ajuizadas depois de já terem as partes submetido sua pretensão a uma Câmara Extrajudicial de Mediação, como corre, por exemplo, na Itália, a partir da promulgação do Decreto Legislativo $n^{\circ}$ 28/2010.

8. Ao homologar acordos extrajudiciais, o Poder Judiciário promove meramente um juízo de delibação sobre a causa. Equiparar tal juízo, do ponto de vista substancial, a uma sentença judicial seria algo utópico e pouco conveniente. Atribuir eficácia de coisa julgada a tal atividade implicaria conferir um definitivo e real a um juízo meramente sumário, quando não, muitas vezes, ficto. Admitir que o judiciário seja utilizado para esse fim é diminuir-lhe a importância, é equipará-lo a um mero cartório, função para a qual ele não foi concebido. 9. Recurso especial não provido. (REsp 1184151/MS, Ministro Relator Massami Uyeda, Rel. p/ Acórdão Ministra Nancy Andrighi, Terceira Turma, julgado em 15/12/2011, DJe 09/02/2012).

Esse acórdão foi proferido levando em consideração a redação do art. 475-N, do CPC/73 e o art. 57 da Lei 9.099/95, que inspiraram o texto do art. 515, III do CPC/2015. Por isso, Daniel Neves sustenta que, em relação ao STJ, "nada indica que no Novo Código de Processo Civil o entendimento será modificado" (NEVES, Op. Cit., p. 1115).

Na doutrina, Teori Zavascki também apresentou argumentos semelhantes aos expostos pelo STJ: "A função jurisdicional existe para dirimir conflitos, sendo que a sentença homologatória de transação representa instrumento para atingir esta finalidade. Não se pode provocar a jurisdição para, simplesmente, homologar negócio jurídico de transação previamente celebrado. Se houve transação antes do ajuizamento, a controvérsia não mais existe e a função jurisdicional é desnecessária”. (ZAVASCKI, Teoria Albino. Comentários ao código 
da autocomposição extrajudicial advém da necessidade de se conferir maior segurança à avença, pois a partir de sua homologação o seu conteúdo não poderá ser mais questionado, salvo por meio de ação própria. Reforça o argumento a possibilidade, agora também trazida pelo Código (art. $785^{26}$ ), de o credor detentor de título extrajudicial promover ação de conhecimento visando a obtenção de título judicial.

Além disso, a homologação pelo Poder Judiciário é capaz de assegurar uma execução mais efetiva, ${ }^{27}$ pois o título executivo judicial só poderá ser questionado por meio da impugnação, que, em regra, não possui efeito suspensivo e contém um rol limitado de matérias que podem ser arguidas.

\subsection{RITO PROCEDIMENTAL: APLICAÇÃO DAS DISPOSIÇÕES GERAIS} DO PROCEDIMENTO DE JURISDIÇÃO VOLUNTÁRIA

Uma das novidades do CPC/2015 é a previsão contida no art. 725, VIII, que determina seja o pedido de homologação de autocomposição extrajudicial, de qualquer natureza ou valor, processado conforme as disposições gerais dos procedimentos de jurisdição voluntária.

Essa norma é consolidação de entendimento doutrinário firmado na vigência do CPC/73. Como o antigo diploma processual nada dizia sobre o procedimento a ser adotado, a doutrina ${ }^{28}$ sustentava que o rito a ser percorrido era aquele previsto nos artigos $1.103 \mathrm{e}$ seguintes, que tratavam justamente das disposições gerais dos procedimentos de jurisdição voluntária, consoante rege agora expressamente o CPC/2015.

de processo civil: do processo de execução, arts. 566 a 645. 2. ed . São Paulo: Revista dos Tribunais, 2003, pp. 188-189)

${ }^{26}$ Art. 785. A existência de título executivo extrajudicial não impede a parte de optar pelo processo de conhecimento, a fim de obter título executivo judicial.

${ }^{27}$ ARRUDA ALVIM, Teresa. Nulidades do processo e da sentença. 8. ed. São Paulo: Revista dos Tribunais, 2017, p. 107.

${ }^{28}$ Cf. GRECO, Op. Cit., p. 124; BUENO, Cassio Scarpinella. A nova etapa da reforma do Código de Processo Civil, volume 1: comentários sistemáticos às Leis n. 11.187, de 19-10-2005, e 11.232, de 22-12-2005. 2. ed. São Paulo: Saraiva, 2006, p. 168-169; MONTENEGRO FILHO, Misael. Código de processo civil comentado e interpretado. São Paulo: Atlas, 2008, p. 525; DIDIER JR. et al. Op. Cit., p. 171; ARRUDA ALVIM WAMBIER, Teresa et. al. (coord.). Primeiros comentários ao novo código de processo civil: artigo por artigo. 2. ed. rev., atual. e ampl. São Paulo: Revista dos Tribunais, 2016, p. 935. 
A petição inicial deve estar acompanhada do instrumento de autocomposição extrajudicial a ser objeto de homologação. Trata-se de documento indispensável, cuja ausência implica despacho para a complementação da inicial, sob pena de indeferimento.

Caso a petição não esteja assinada por todos os interessados, serão citados aqueles cuja anuência não conste na inicial para se manifestar no prazo de 15 dias. ${ }^{29}$

Após o decurso do prazo para a manifestação da parte constante no polo passivo, o Ministério Público será intimado, no mesmo prazo, se o caso exigir a sua presença como fiscal da ordem jurídica (art. 178 do CPC/2015).

Também será necessária a oitiva da Fazenda Pública, quando o objeto da autocomposição extrajudicial lhe disser respeito.

Em seguida, o juiz terá o prazo de dez dias para proferir a decisão de homologação ou de indeferimento do pedido.

O papel do juiz é de fazer o chamado juízo de delibação, de forma a verificar a presença dos requisitos formais do negócio jurídico (capacidade, representação regular, disponibilidade do direito). ${ }^{30}$

Caso o pedido de homologação da autocomposição extrajudicial seja indeferido, ou seus termos sejam homologados apenas parcialmente, caberá apelação. ${ }^{31}$

Se as partes anuírem, no prazo da manifestação, sobre os termos da autocomposição, e for o caso de atendimento integral do pedido da inicial, não haverá interesse recursal em apelar, ${ }^{32}$ salvo por um terceiro interessado, que eventualmente possa se sentir prejudicado.

\footnotetext{
${ }^{29}$ Essa deverá ser a regra no caso de processo eletrônico, em que apenas uma das partes pode assinar eletronicamente a petição. Como precaução e visando à celeridade, é possível que a parte considerada autora apresente desde logo documento da outra parte anuindo com os termos da autocomposição que estão sendo apresentados.

${ }^{30}$ DINAMARCO, Cândido Rangel. Instituições de Direitos Processual Civil. 3. ed. São Paulo: Malheiros, 2009, vol. 4, p. 264. No mesmo sentido, MARINONI, Luiz Guilherme; ARENHART, Sérgio Cruz; MITIDIERO, Daniel. Novo curso de processo civil: tutela dos direitos mediante procedimento comum, volume 2. 3 ed. São Paulo: Revista dos Tribunais, 2017, p. 844; FUX, Luiz. O novo processo de execução (cumprimento da sentença e a execução extrajudicial). Rio de Janeiro: Forense, p. 46.

${ }^{31}$ Art. 724. Da sentença caberá apelação.

32 Em estudo feito à época da vigência do CPC anterior, Wagner Júnior defendia que a homologação da autocomposição extrajudicial pelo juiz fazia incidir a preclusão lógica sobre o ato de recorrer das partes. Segundo o autor, as partes renunciam tacitamente ao prazo recursal ao formularem pedido de homologação de autocomposição extrajudicial, consoante disposição constante no art. 503 do CPC/73 (cuja redação é semelhante ao atual art. 1.000 do CPC). Cf. WAGNER JÚNIOR, Op. cit., p. 489.
} 


\subsection{O QUE SIGNIFICA A EXPRESSÃO "QUALQUER NATUREZA"} CONTIDA NO ART. 515, III E NO ART. 725, VIII, DO CPC/2015?

Como visto, o art. 515, III, do CPC/2015 dispõe que é título executivo judicial a decisão homologatória de autocomposição extrajudicial de qualquer natureza. Já o art. 725, VIII determina que o pedido de homologação de autocomposição extrajudicial, de qualquer natureza ou valor, será processado conforme as regras do procedimento de jurisdição voluntária.

A doutrina, em geral, apresenta três significados à expressão "qualquer natureza": um relacionado à disponibilidade do direito; um segundo que diria respeito à obrigação instituída pela autocomposição; e um terceiro equivalente a "qualquer matéria", o que atrairia a dúvida sobre a competência do juízo.

\subsubsection{AUTOCOMPOSIÇÃO EXTRAJUDICIAL DE DIREITOS}

\section{DISPONÍVEIS E INDISPONÍVEIS}

Uma das possíveis interpretações a respeito da expressão "qualquer natureza" é no sentido de que a autocomposição pode tratar de qualquer direito. Mas é possível autocompor sobre direito indisponível?

Parte da doutrina entende que o objeto da autocomposição extrajudicial deve se limitar a direitos disponíveis. ${ }^{33}$ Entendemos, porém, de forma diversa. É indiferente, sob o viés da possibilidade jurídica, a disponibilidade ou indisponibilidade do direito. ${ }^{34}$

Dizer que um direito é indisponível não significa que ele não admita negociação. É o caso, por exemplo, do Direito de Família, que tutela diversos direitos indisponíveis, mas que autoriza a transação sobre os seus efeitos pecuniários. ${ }^{35} \mathrm{O}$ mesmo sucede com os direitos transindividuais e individuais homogêneos, reconhecidamente indisponíveis, contudo

\footnotetext{
${ }^{33}$ CRUZ, Aloysio Álvares. A transação, a conciliação e o acordo extrajudicial. Revista de Jurisprudência do Tribunal de Justiça de São Paulo. Vol. 109 - ano 21 - 6º bimestre, novembro e dezembro de 1987, p. 10; SANTOS, Ernane Fidélis dos. As reformas de 2005 e 2006 do Código de Processo Civil: execução dos títulos judiciais e agravo de instrumento. 2. ed. São Paulo: Saraiva, 2006, p. 38; ABELHA, Marcelo. Manual de execução civil. 6. ed. Rio de Janeiro: Forense, 2016, p. 150.

${ }^{34}$ ASSIS, Araken de. Manual da execução. 19 ed. São Paulo: Revista dos Tribunais, 2017, p. 238.

${ }^{35}$ TARTUCE, Fernanda. Lei $\mathrm{n}^{\circ}$ 11.232/05, art. 475-N, inciso IV (sic): acordo extrajudicial de qualquer natureza homologado em juízo como título executivo judicial. Revista EPD - Escola Paulista de Direito. Ano 2, n. 3 (out./nov. 2006), 2006, p. 243.
} 
passíveis de transação. Ou também os direitos trabalhistas que não admitem renúncia, mas são transacionáveis. ${ }^{36} \mathrm{Ou}$ o que dizer do direito penal, que trata sobre o maior dos direitos indisponíveis - a liberdade -, mas que admite a transação penal ${ }^{37}$

Concluímos com Fernanda Tartuce, para quem o alcance da expressão "acordo de qualquer natureza" 38 abarca uma ampla noção de disponibilidade dos direitos, sendo possível a transação não só sobre direitos disponíveis, mas também sobre aspecto(s) quantitativo(s) dos direitos indisponíveis. ${ }^{39}$

\subsubsection{AS OBRIGAÇÕES ACORDADAS EM AUTOCOMPOSIÇÃO} EXTRAJUDICIAL

Ao mencionar que é título executivo judicial a decisão que homologa autocomposição extrajudicial de qualquer natureza, o art. 515, III requer que seja estabelecida uma obrigação por meio do acordo entre as partes. Para ser título executivo, há a necessidade que alguém estabeleça um dever de prestar que deverá ser cumprido pelo outro sujeito. ${ }^{40}$ Por conseguinte, não é título executivo judicial uma decisão homologatória de renúncia a determinado direito ou uma sentença homologatória de transação a respeito da anulação de um contrato. ${ }^{41}$

Ao comentar o art. 725, VIII do CPC/2015, Marcato ${ }^{42}$ afirma que "a composição poderá ter por objeto obrigação de pagar determinada quantia, de entregar coisa ou de fazer ou não fazer".

Assim, a autocomposição extrajudicial de qualquer natureza está relacionada também à modalidade de cumprimento da obrigação pactuada.

\footnotetext{
36 Vale lembrar que a Lei 13.467/2017 inseriu na CLT a possibilidade de a Justiça do Trabalho homologar acordo extrajudicial, o que era repudiado pela jurisprudência.

${ }^{37}$ Amplamente sobre o tema da transação de direitos indisponíveis, cf. VENTURI, Elton. Transação de direitos indisponíveis? Revista de Processo, vol. 251 (janeiro de 2016).

${ }^{38} \mathrm{Na}$ redação atual, não há mais referência a acordo, mas sim a autocomposição extrajudicial de qualquer natureza.

39 TARTUCE, Op. Cit., p. 245.

${ }^{40}$ ASSIS, Op. Cit., p. 238.

${ }^{41} \mathrm{O}$ último exemplo é de ABELHA, Op. Cit., p. 150.

42 MARCATO, Antônio Carlos. Procedimentos especiais. 17. ed. São Paulo: Atlas, 2017, p. 323.
} 


\subsubsection{A COMPETÊNCIA DO JUÍZO PARA PROFERIR DECISÃO HOMOLOGATÓRIA DE AUTOCOMPOSIÇÃO EXTRAJUDICIAL}

Uma das maiores polêmicas envolvendo a homologação de autocomposição extrajudicial estava relacionada à competência do juízo. Isso porque a lei utilizou as expressões "qualquer matéria" e "juízo competente" para autorizar esse procedimento, mas a previsão legal foi inserida em leis específicas, fora do CPC/73.

Surgiu, assim, a dúvida se os Juizados de Pequenas Causas e os Juizados Especiais poderiam homologar autocomposição extrajudicial a respeito de quaisquer matérias. Posteriormente, com a inserção de texto similar no CPC/73, esse questionamento perdeu o seu sentido, mas outro surgiu: caberia às partes a escolha do juízo responsável por homologar a autocomposição extrajudicial, já que é possível a homologação de qualquer matéria?

Para responder essas perguntas, é cogente fazermos uma interpretação histórica, a partir da doutrina da época, dos textos de lei que resultaram nas normas construídas a partir do art. 515, III e art. 725, VIII, do CPC/2015.

No breve histórico exposto no item 2, vimos que a Lei 7.244/84 foi a primeira a dispor, em seu art. 55, que o acordo extrajudicial, de qualquer natureza ou valor, poderia ser homologado, no juízo competente, independentemente de termo, valendo a sentença como título executivo judicial. Essa redação foi mantida pelo art. 57 da Lei 9.099/95 e, mais tarde, repetida no $\mathrm{CPC} / 73$.

A norma que se construía a partir do art. 55 da Lei 7.244/84, e se constrói a partir do art. 57 da Lei 9.099/95, sempre ultrapassou o âmbito dos juizados. Ela foi inserida em legislação especial, mas abrangia tanto as relações jurídicas alcançadas por aquelas leis como outras que refugiam da competência dos Juizados de Pequenas Causas e dos Juizados Especiais Cíveis.

Em outras palavras, a autocomposição extrajudicial era título executivo judicial não só quando homologada pelo juízo de Juizado das Pequenas Causas e de Juizado Especial Cível, mas também quando homologada por outro juízo, desde que a matéria levada a ele estivesse dentro de sua competência. Mesmo antes da importação daquela norma pelo CPC/73, era possível que os transatores convertessem a autocomposição extrajudicial, que 
já poderia ser um título executivo extrajudicial, em título executivo judicial, caso o acordo

\author{
fosse levado à homologação na Justiça Comum. ${ }^{43-44-45-46-47-48-49-50-51-52-53}$
}

43 "A homologação deve ser pleiteada: no juizado especial, se dentro da competência deste (v. arts. $3^{\circ}$ e $8^{\circ}$ ); no juízo comum, em todas as demais hipóteses (neste sentido: RJTJESP 118/269, JTJ 142/167, maioria)". (NEGRÃO, Theotonio; GOUVÊA, José Roberto Ferreira; BONDIOLI, Luiz Guilherme Aidar (colaborador). Código de Processo Civil e legislação processual em vigor. 40. ed. São Paulo: Saraiva, 2008, p. 1645, nota 2 referente ao art. 57 da Lei 9.099/95).

44 "Esse procedimento que busca exclusivamente a homologação de autocomposição não é de aplicação exclusiva nos juizados especiais. O simples fato de o dispositivo legal que criou o processo exclusivo para requerer a homologação da autocomposição estar inserto na lei que instituiu os Juizados Especiais não tem a consequência de limitar sua aplicação a esses juizados, devendo prevalecer sua redação genérica e incondicional". (CALMON, Petrônio. Fundamentos da mediação e da conciliação. 2. ed. Brasília/DF: Gazeta Jurídica, 2013, p. 72).

45 "Quando o título judicial a executar for acordo homologado pelo juizado especial (LJE, art. 57), a competência deste limitar-se-á aos casos em que a natureza da pretensão e o seu valor o permitirem (art. $3^{\circ}$ : v. supra, n. 124). Mas, quando a causa for de natureza ou valor incompatível com a competência do juizado, é preciso procurar o órgão comum competente". (DINAMARCO, Op. Cit., 2000, p. 215)

46 "A possibilidade de o juiz homologar acordos extrajudiciais já era ampla, nos termos do art. 57 da Lei ${ }^{\circ}$ 9.099/95 (Lei dos Juizados Especiais), que repetia, nesse sentido, dispositivo da lei anterior (de 1984), sendo certo que o mecanismo legal não tinha - e continua a não ter - eficácia restrita ao âmbito dos Juizados". (MARCATO, Antonio Carlos (coord.). Código de processo civil interpretado. 3. Ed. São Paulo: Atlas, 2008, p. 1618)

47 "Esse dispositivo, na verdade, na medida em que se refere a acordo de qualquer natureza ou valor, transcende a Lei n. 9.099/95. Por ele, não deve ser entendido, em hipótese nenhuma, que qualquer acordo pode ser homologados pelos Juizados Especiais Cíveis. Deve ser observada a regra do juízo competente, sob pena de nulidade." (SILVA, Jorge Alberto Quadros de Carvalho. Lei dos juizados especiais cíveis anotada: (doutrina e jurisprudência dos 27 Estados da Federação). 2. ed. São Paulo: Saraiva, 2001, p. 183).

48 "Essa regra não é regra específica do Juizado Especial; é regra de direito comum, aplicável em qualquer juízo. A norma prevê a transação, em matéria de qualquer natureza, ou envolvendo qualquer valor, devendo ser homologado no juízo competente. Trata-se, portanto, de norma de caráter geral, com aplicação, inclusive, no Juizado Especial”. (MOREIRA, Wander Paulo Marotta. Juizados especiais cíveis. Belo Horizonte: Del Rey, 1996, p. 52)

49 “O dispositivo retro é aplicável não apenas ao Juizado Especial, mas também ao Juízo Comum. Portanto, é possível o pedido de homologação de acordo extrajudicial no Juízo competente, seja qual for o seu montante e seja qual for a matéria, desde que se trata de direito passível de disposição. A homologação do acordo ocorrerá no Juizado Especial se a matéria do mesmo estiver contida na esfera de competência deste (arts. $3^{\circ}$ e $8^{\circ}$, da Lei)". (MELO, José Maria de; TEÓFILO NETO, Mário Parente. Lei dos juizados especiais: comentada. $1^{\circ}$ ed., $2^{\mathrm{a}}$ tir. Curitiba: Juruá, 1997, p. 86-87)

50 "A competência a que se refere esse dispositivo há de ser, indiscutivelmente, a do Juízo competente para conhecer o pedido. Desta forma, a competência do Juizado Especial Cível, para fins de homologação de acordo extrajudicial, cinge-se às causas previstas no art. $3^{\circ}$ desta Lei, bem como àquelas que não foram excluídas do âmbito de sua competência (art. $3^{\circ}, \S^{\circ}$ ). Vê-se que esta regra tem alcance geral, não sendo, em absoluto, aplicável somente aos Juizados Especiais". (COSTA, Hélio Martins. Lei dos juizados especiais cíveis anotada e sua interpretação jurisprudencial. Belo Horizonte: Del Rey, 1998, p. 211-212)

51 "A homologação dos acordos extrajudiciais que versem sobre questões diversas daquelas previstas no art. $3^{\circ}$ da lei especial, que envolvam qualquer daqueles impedidos de participar do novo sistema (art. $8^{\circ}$ da Lei $n$. 9.099/95) ou que traduzam valores superiores a quarenta salários mínimos, é de competência dos meritíssimos juízes das Varas comuns". (CHIMENTI, Ricardo Cunha. Teoria e prática dos juizados especiais cíveis. 2. ed. São Paulo: Saraiva, 1999, p. 241).

${ }^{52}$ MAIA, Daniel Netto. Da possibilidade e utilidade da homologação em juízo de acordos extrajudiciais independentemente da prévia instauração de processo judicial. Revista Jus Navigandi, ISSN 1518-4862, Teresina, ano 18, n. 3733, 20 set. 2013. Disponível em: https://jus.com.br/artigos/25347. Acesso em: 16 dez. 2020. 
Chega-se a essa conclusão porque o próprio texto da lei menciona que o acordo extrajudicial poderia ser homologado por sentença no juízo competente. O juízo deve ser relativamente, mas, principalmente, absolutamente competente.

Os Juizados das Pequenas Causas não detinham e os Juizados Especiais Cíveis não detêm competência para homologar autocomposição extrajudicial que verse sobre matérias de competência da Justiça Comum ou da Justiça Especial (trabalhista, militar, eleitoral). ${ }^{54-55-56}$ Afinal, a competência absoluta envolve questão de ordem pública, que pode ser reconhecida a qualquer tempo e o seu desrespeito dá ensejo, inclusive, à ação rescisória.

Se havia dúvida sobre a aplicação do art. 57 da Lei 9.099/95 fora do âmbito dos Juizados Especiais, o questionamento passou a não fazer mais qualquer sentido a partir da inserção da norma no art. 475-N, V, do CPC/73. ${ }^{57}$

\footnotetext{
${ }^{53}$ Aparentemente entendendo que o acordo extrajudicial somente passou a ser homologável perante a Justiça Comum após a inserção de previsão legal específica no CPC/73, cf. ARRUDA, ALVIM, Op. Cit., p. 107.

${ }^{54}$ LEITE, Maria Auxiliadora Sobral. Juizados Especiais Cíveis: processo de conhecimento. In: FARIAS, Cristiano Chaves de; DIDIER JR., Fredie (coord.). Procedimentos especiais cíveis: legislação extravagante. São Paulo: Saraiva, 2003, p. 478; BUENO, Cassio Scarpinella. Curso sistematizado de direito processual civil: procedimentos especiais do Código de Processo Civil. Juizados Especiais, vol. 2, tomo II. 2. ed. São Paulo: Saraiva, 2013, p. 242.

${ }^{55}$ Parte da doutrina manifestou entendimento no sentido de que lei local poderia conferir competência aos Juizados das Pequenas Causas para homologar autocomposição extrajudicial sobre matéria que não fosse originalmente de sua competência. Cf. WATANABE, Kazuo [et al.]. Juizado especial de pequenas causas: Lei n. 7.244, de 7 de novembro de 1984. São Paulo: Revista dos Tribunais, 1985, p. 192, nota 36.

${ }^{56}$ Pensamento parcialmente diverso é exposto por Joel Dias Figueira Júnior: "Observadas as limitações instituídas no art. $8^{\circ}$ da Lei 9.099/95, o legislador abriu um enorme leque em sede de competência dos Juizados Especiais Cíveis para fins de conciliação, como verdadeira exceção às regras insculpidas no art. $3^{\circ}$, inciso I (valor) e $\S 2^{\circ}$ (matéria). Significa dizer que os limites referidos têm pertinência tão-somente no que concerne às lides institucionalizadas, ou seja, para fins de resolução de conflitos em sede adversarial (lide e processo jurisdicionalizados). Em síntese, segundo o próprio texto legal, as matérias de quaisquer natureza e valor (inexistência de limite qualitativo ou quantitativo) podem ser objeto de acordo e homologadas perante o juiz togado dos Juizados Especiais, ampliando-se, em muito, o espectro da autocomposição". (TOURINHO NETO, Fernando da Costa; FIGUEIRA JÚNIOR, Joel Dias. Juizados Especiais Estaduais Cíveis e Criminais: Comentários à Lei 9.099/1995. 5.ed. São Paulo: Revista dos Tribunais, 2007, p. 363)

Deve-se destacar que em obra anterior, em co-autoria com Mauricio Antonio Ribeiro Lopes, Figueira Júnior manifestou entendimento em parte diverso, pois dizia que a expressão "qualquer natureza" deveria ser interpretada "em sintonia com as limitações assinaladas no próprio microssistema, que excluem da competência dos Juizados Especiais algumas demandas em razão da matéria $\left(\operatorname{art.} 3^{\circ}, \S 2^{\circ}\right.$ ) e das pessoas (art. $8^{\circ}$, caput e $\left.\S^{\circ}\right)^{\circ}$.' Para ele, não haveria limitação de valor e de matéria para fins de homologação de acordo extrajudicial, salvo quanto às restrições impostas pela própria lei e contidas no art. $3^{\circ}, \S 2^{\circ}$ e art. $8^{\circ}$, caput e $\S 1^{\circ}$. (FIGUEIRA JÚNIOR, Joel Dias; LOPES, Mauricio Antônio Ribeiro. Comentários à lei dos juizados especiais cíveis e criminais: Lei 9.099, de 26.09.1995. 3 ed. São Paulo: Revista dos Tribunais, 2000, p. 405)

${ }^{57}$ Nesse sentido: "O caput do art. 57 da Lei n. 9.099/1995 prevê que o acordo extrajudicial, de qualquer natureza ou valor, poderá ser homologado, no juízo competente, independentemente de termo, valendo a sentença como título executivo judicial. A regra acabou sendo generalizada pela Lei n. 11.232/2005 que a incluiu no inciso V do art. 475-N do Código de Processo Civil, e deu por encerrada dúvida pertinente sobre se a hipótese de incidência do referido art. 57 deveria se circunscrever aos Juizados Especiais Cíveis ou não". (BUENO, Cassio Scarpinella. Curso sistematizado de direito processual civil: procedimentos especiais do Código de Processo Civil. Juizados Especiais, vol. 2, tomo II. 2. ed. São Paulo: Saraiva, 2013, p. 242).
} 
A interpretação dada pela doutrina ao art. 475-N, V, do CPC/73 estava em consonância com aquela formada a respeito do art. 57 da Lei 9.099/95: não havia opção de escolha das partes sobre o juízo responsável pela homologação do acordo extrajudicial caso a autocomposição tratasse de matéria que deveria ser apreciada por juízo absolutamente competente. $^{58}$

A conclusão a respeito da competência do juízo responsável por homologar a autocomposição extrajudicial permanece na interpretação do art. 515, III e do art. 725, VIII, do CPC/2015. A autocomposição feita fora do processo pelas partes pode envolver qualquer matéria ou valor, desde que respeitada a competência do juízo responsável por homologá1a. ${ }^{59}$ Didaticamente, exemplifica Marcelo José Magalhães Bonicio ${ }^{60}$ :

Dessa forma, por exemplo, para homologar um acordo a respeito de um contrato comercial, não podem as partes optar pelo juízo que cuida exclusivamente do direito de família, ou das execuções fiscais, numa determinada comarca, mas sim o juízo que, em tese, seria competente para a ação correspondente ao litígio que existiria, caso não houvesse um acordo.

E essa é a regra: o pedido de homologação de autocomposição extrajudicial deve ser dirigido ao juízo que seria competente para julgar o objeto do acordo, caso ele fosse litigioso.

Seguindo essa linha de raciocínio, um Juiz do Trabalho não pode homologar autocomposição extrajudicial que verse sobre complementação de aposentadoria por entidades de previdência privada, pois o STF já decidiu que aquela matéria é de competência da Justiça Comum. ${ }^{61}$

Da mesma forma, um Juiz Estadual não pode homologar uma autocomposição extrajudicial que trate sobre matéria de competência da Justiça do Trabalho. Como é cediço, a competência da Justiça do Trabalho é prevista constitucionalmente (art. 114, da CF/88 ${ }^{62-}$

\footnotetext{
${ }^{58}$ Nesse sentido: DIDIER JR. et al. Op. cit., p. 170; BONICIO, Marcelo José Magalhães. Comentários ao art. 475-N, V, do CPC/73. In: ARMELIN, Donaldo et. al. Comentários à execução civil: título judicial e extrajudicial (artigo por artigo) - de acordo com as Leis n. 11.232/2005 e 11.382/2006. São Paulo: Saraiva, 2008, p. 92.

59 SHIMURA, Sérgio. Comentários ao art. 515. In: ARRUDA ALVIM WAMBIER, Teresa et al. (coord.). Breves comentários ao novo código de processo civil. 3. ed. São Paulo: Revista dos Tribunais, 2016, p. 1470. ${ }^{60}$ BONICIO, Op. Cit., p. 92.

${ }^{61}$ STF, RE 586453 e RE 583050, Ministra Relatora Ellen Gracie, Min. Relator p/ Acórdão Dias Toffoli, Tribunal Pleno, julgado em 20/02/2013, publicado em 06/06/2013.

62 BRASIL. Constituição da República Federativa do Brasil de 1988. Disponível em: http://www.planalto.gov.br/ccivil_03/constituicao/constituicao.htm. Acesso em: 16 dez. 2020.
} 
${ }^{63}$ ). A competência é absoluta e, portanto, irrevogável e não pode ser objeto de acordo entre as partes ${ }^{64}$.

Poder-se-ia argumentar ser essa conclusão insustentável, porquanto o juízo da Vara de Família seja competente para homologar autocomposição extrajudicial que diga respeito ao pagamento de verba alimentícia a determinada criança por meio de desconto salarial do seu pai, empregado de certa sociedade empresária.

Ocorre que a autocomposição, neste caso, recai sobre verba alimentar titularizada pela criança, matéria cuja competência é do juízo da Vara de Família. O fato de envolver desconto salarial em folha de pagamento do pai do menor não torna aquele juízo incompetente, porque diz respeito à forma de cumprimento da obrigação prevista inclusive no art. 529 do $\mathrm{CPC} / 2015$.

Diversamente, o juízo da Justiça Comum é absolutamente incompetente para homologar autocomposição extrajudicial que verse sobre a relação jurídica material de competência da Justiça do Trabalho. Seria o caso de autocomposição em que o empregado transaciona que, em troca do recebimento de determinado valor, dá quitação do extinto contrato de trabalho. Aqui, há nítida autocomposição de direito material que refoge à competência do juízo estadual ou federal comum.

Questão mais complexa é saber qual é o juízo competente quando a autocomposição extrajudicial contém cláusulas que deveriam ser analisadas por juízos de competências diversas.

Imagine o seguinte caso hipotético: uma empresa individual de responsabilidade limitada (Eireli) pactua com determinada sociedade empresária o distrato de um contrato de

\footnotetext{
${ }^{63}$ Art. 114. Compete à Justiça do Trabalho processar e julgar: I as ações oriundas da relação de trabalho, abrangidos os entes de direito público externo e da administração pública direta e indireta da União, dos Estados, do Distrito Federal e dos Municípios; II as ações que envolvam exercício do direito de greve; III as ações sobre representação sindical, entre sindicatos, entre sindicatos e trabalhadores, e entre sindicatos e empregadores; IV os mandados de segurança, habeas corpus e habeas data, quando o ato questionado envolver matéria sujeita à sua jurisdição; V os conflitos de competência entre órgãos com jurisdição trabalhista, ressalvado o disposto no art. 102, I, o; VI as ações de indenização por dano moral ou patrimonial, decorrentes da relação de trabalho; VII as ações relativas às penalidades administrativas impostas aos empregadores pelos órgãos de fiscalização das relações de trabalho; VIII a execução, de ofício, das contribuições sociais previstas no art. 195, I, a , e II, e seus acréscimos legais, decorrentes das sentenças que proferir; IX outras controvérsias decorrentes da relação de trabalho, na forma da lei.

${ }^{64}$ Também nesse sentido o Enunciado 20 do Fórum Permanente de Processualistas Civis (FPPC): "Não são admissíveis os seguintes negócios bilaterais, dentre outros: acordo para modificação da competência absoluta, acordo para supressão da primeira instância, acordo para afastar motivos de impedimento do juiz, acordo para criação de novas espécies recursais, acordo para ampliação das hipóteses de cabimento de recursos".
} 
representação comercial. Além das obrigações reciprocamente pactuadas, os termos da autocomposição contemplam uma cláusula que dispõe que o único sócio da Eireli reconhece ter recebido integralmente as verbas trabalhistas decorrentes de vínculo empregatício entre as partes em momento anterior ao do contrato de representação comercial, quando ele prestou serviços como vendedor viajante ou pracista. ${ }^{65} \mathrm{O}$ pacto é assinado pelo único sócio como representante da Eireli e como parte no acordo, assim como pela sociedade empresária.

Questiona-se: qual o juízo competente para homologar o pedido de autocomposição extrajudicial?

Neste ponto, e de acordo com as lições já expostas, sustentamos que a autocomposição extrajudicial que contenha várias cláusulas, de forma que algumas sejam de competência para apreciação da Justiça Comum, enquanto outras sejam de competência para análise pela Justiça do Trabalho, não pode ser homologada em sua completude, seja pelo Juiz de Direito, seja pelo Juiz do Trabalho.

Quer isso dizer que o Juiz Estadual pode homologar a autocomposição apenas quanto às cláusulas que digam respeito à sua competência. $\mathrm{O}$ mesmo raciocínio se aplica ao Juiz do Trabalho, que está limitado a homologar autocomposição extrajudicial de competência da Justiça do Trabalho. ${ }^{66}$

Nos casos em que há autocomposição extrajudicial com cláusulas que envolvem matérias que devem ser apreciadas por juízos de competências absolutas diversas, uma alternativa para as partes é a submissão em separado dos termos da autocomposição aos diferentes juízos, de acordo com a competência de cada um.

Por fim, cabe ressaltar que há um caso em que o mesmo juízo poderá apreciar a autocomposição extrajudicial que envolva matérias de competência da Justiça do Trabalho

\footnotetext{
${ }^{65}$ A referida situação foi inspirada em dois processos julgados pelo TST, que concluíram de forma diversa sobre a existência de coisa julgada material formada a partir de homologação de acordo extrajudicial na Justiça Comum, em que os trabalhadores, posteriormente, recorreram à Justiça do Trabalho para discutir a relação jurídica entre as partes: TST, RO - 142700-45.2009.5.15.0000, Ministro Relator Alberto Luiz Bresciani de Fontan Pereira, Subseção II Especializada em Dissídios Individuais, Data de Julgamento: 01/12/2015, Data de Publicação: DEJT 04/12/2015 e TST, Ag-ED-E-ED-ARR - 3020-79.2014.5.17.0011, Ministro Relator Luiz Philippe Vieira de Mello Filho, Subseção I Especializada em Dissídios Individuais, Data de Julgamento: 07/06/2018, Data de Publicação: DEJT 15/06/2018. Mais recentemente, aquela Corte voltou a se pronunciar sobre a matéria no E-ED-RR-115-05.2010.5.04.0561, Ministro Relator Augusto César Leite de Carvalho, SBDI-I, Data de Julgamento: 24/10/2019.

${ }^{66}$ A Lei n. 13.467/2017, também chamada de Reforma Trabalhista, incluiu o inciso "f" no rol do art. 652. que assim dispõe: "Art. 652. Compete às Varas do Trabalho: f) decidir quanto à homologação de acordo extrajudicial em matéria de competência da Justiça do Trabalho". Essa mesma lei disciplinou o procedimento de homologação de acordo extrajudicial na Justiça do Trabalho, consoante artigos 855-B a 855-E, da CLT.
} 
e da Justiça Estadual. As partes que estão situadas em comarca não abrangida por jurisdição da Justiça do Trabalho podem submeter a autocomposição extrajudicial, envolvendo matéria tanto da Justiça do Trabalho quanto da Justiça Estadual, ao juiz de direito local. ${ }^{67}$ Trata-se de hipótese em que a própria Constituição Federal confere a juiz de direito a competência absoluta exclusiva da Justiça do Trabalho. Formalmente, tem-se atuação da Justiça Comum por meio do juiz de direito, mas substancialmente este atua com competência juslaboral por delegação constitucional.

\section{A DECISÃO HOMOLOGATÓRIA DE AUTOCOMPOSIÇÃO} EXTRAJUDICIAL E A COISA JULGADA

É possível que um juízo absolutamente incompetente homologue autocomposição extrajudicial e a decisão homologatória transite em julgado.

Grande parte da doutrina argumenta que a decisão homologatória de autocomposição extrajudicial somente pode ser impugnada por ação anulatória (art. 966, §4 do $\mathrm{CPC} / 2015)^{68}$. Essa corrente doutrinária sustenta que não há coisa julgada material na jurisdição voluntária, restando apenas a ação anulatória como forma de impugnar a decisão judicial. ${ }^{69}$

Outra parte da doutrina, sem entrar na discussão específica a respeito da incompetência, aduz que toda vez que for verificado vício na vontade das partes caberá o ajuizamento da ação anulatória. ${ }^{70}$

\footnotetext{
${ }^{67}$ Constituição Federal. Art. 112. A lei criará varas da Justiça do Trabalho, podendo, nas comarcas não abrangidas por sua jurisdição, atribuí-la aos juízes de direito, com recurso para o respectivo Tribunal Regional do Trabalho.

${ }^{68}$ Art. 966, $\S 4^{\circ}$. Os atos de disposição de direitos, praticados pelas partes ou por outros participantes do processo e homologados pelo juízo, bem como os atos homologatórios praticados no curso da execução, estão sujeitos à anulação, nos termos da lei.

${ }^{69}$ MARQUES, José Frederico. Ensaio sobre a jurisdição voluntária. Campinas: Millennium, 2000, passim; PRATA, Edson. Jurisdição Voluntária. São Paulo: Livraria e Editora Universitária de Direito Ltda, 1979; MARCATO, Op. cit., 2017, p. 11; THEODORO JR., Humberto. Curso de Direito Processual Civil Procedimento Especiais - vol. II. 50 a ed. Rio de Janeiro: Forense, 2016, p. 445; GRECO, Leonardo. Comentários ao art. 725. In: ARRUDA ALVIM WAMBIER, Teresa et al. (coord.). Breves comentários ao novo código de processo civil. 3. ed. São Paulo: Revista dos Tribunais, 2016, p. 1867.

${ }^{70}$ MARINONI; ARENHART; MITIDIERO. Op. Cit., p. 844; ARRUDA ALVIM, Op. Cit. p. 107.
} 
Seguimos outro caminho. A decisão homologatória de autocomposição extrajudicial faz coisa julgada material. ${ }^{71}$ Nesse sentido, citamos lição de Fredie Didier Jr. sobre o tema:

É possível pedir a homologação de qualquer acordo extrajudicial ao juízo competente. O procedimento para homologação do acordo extrajudicial é de jurisdição voluntária (art. 725, VIII, CPC). Uma vez homologado, este acordo torna-se título executivo judicial (art. 515, III, CPC). O acordo extrajudicial não homologado judicialmente pode ser considerado um título executivo extrajudicial, preenchidos os demais pressupostos do inciso III do art. 784 do CPC. Há, pois, uma diferença no tratamento normativo do negócio jurídico. A execução de título judicial não permite qualquer discussão; a cognição é limitada, exatamente porque se trata de uma execução de sentença (somente podem ser alegadas as matérias constantes do art. $525, \S 1^{\circ}, \mathrm{CPC}$, quase todas elas relativas a fatos posteriores ao negócio jurídico). A execução de título extrajudicial permite ao executado a alegação de qualquer matéria de defesa, sem limitação alguma (art. 917 do CPC). Qual o fundamento para a diferença do tratamento? A coisa julgada, atributo das decisões judiciais, mesmo homologatórias, mesmo em jurisdição voluntária, impede a rediscussão do que foi decidido (no caso, decisão das partes interessadas homologada pelo juiz). Para compreender a diferença de tratamento entre o negócio jurídico homologado judicialmente e aquele não submetido a essa confirmação, é preciso superar o dogma da ausência de coisa julgada na jurisdição voluntária. ${ }^{72}$

Esse entendimento é reforçado por Petrônio Calmon:

O escopo das partes ao buscar a homologação do acordo não é outro senão obter a segurança que somente a sentença promove. Se a causa pudesse ser revista a qualquer momento por uma das partes, não haveria incentivo para a realização do acordo, que seria comparado a qualquer contrato privado, que gera direitos e obrigações, mas não confere certeza, segurança e imutabilidade. ${ }^{73}$

Em profundo estudo sobre a coisa julgada, confeccionado na época da vigência do CPC/73, Eduardo Talamini concluiu que as sentenças homologatórias de transação, reconhecimento e renúncia são de mérito e, portanto, revestidas de coisa julgada material,

\footnotetext{
${ }^{71}$ Também nesse sentido: BERMUDES, Sérgio. CPC de 2015: inovações. 1. ed. Rio de Janeiro: LMJ Mundo Jurídico, 2018, p. 146.

${ }^{72}$ DIDIER JR., Fredie. Curso de direito processual civil: introdução ao direito processual civil, parte geral e processo de conhecimento. 19. ed. Salvador: Jus Podivm, 2017, p. 219, grifos do autor.

${ }^{73}$ CALMON, Petrônio. Fundamentos da mediação e da conciliação. 2. ed. Brasília/DF: Gazeta Jurídica, 2013, p. 70.
} 
sendo exceções algumas poucas sentenças proferidas em jurisdição voluntária. ${ }^{74} \mathrm{Em}$ assim sendo, essas sentenças homologatórias são impugnáveis pela via da ação rescisória, e não da ação anulatória. ${ }^{75-76}$

Sob a égide do CPC/2015, pode-se afirmar que toda e qualquer decisão de mérito é impugnável mediante ação rescisória, inclusive a decisão de mérito por equiparação, que é aquela prevista no art. 487, III, desde que presente uma das causas de rescindibilidade indicadas no art. 966 do CPC/2015. ${ }^{77}$

Portanto, se o vício que contamina a decisão homologatória de autocomposição extrajudicial é de incompetência absoluta, então é cabível a ação rescisória. Neste caso, essa ação autônoma terá como escopo a rescisão de decisão de mérito prolatada por juízo absolutamente incompetente, o que configura uma das hipóteses legais de cabimento de ação rescisória, conforme art. 966, II, do CPC/2015. ${ }^{78}$

Não faz sentido sustentar o cabimento de ação anulatória quando ela possui como escopo o ataque a atos de disposição das partes, ou de outros participantes do processo, e homologados pelo juízo que contêm vício na manifestação de vontade, o que não é o caso.

Por último, importante destacar que, por se tratar de uma decisão "subjetivamente complexa", formada por um ato de vontade das partes (autocomposição extrajudicial) complementado por um ato de vontade estatal consubstanciado na decisão judicial (homologação), ${ }^{79}$ a declaração de incompetência do juízo não retira eventual eficácia executiva do título executivo extrajudicial, caso preenchidos os requisitos exigidos pelo art. 784 do $\mathrm{CPC} / 2015 .{ }^{80}$

\section{CONCLUSÕES}

\footnotetext{
${ }^{74}$ TALAMINI, Eduardo. Coisa julgada e sua revisão. São Paulo: Revista dos Tribunais, 2005, p. 187.

75 Ibidem, p. 188.

${ }^{76}$ Em sentido diverso, o Pleno do STF, por maioria, decidiu que "a decisão judicial homologatória de acordo entre as partes proferida na vigência do Código de Processo Civil (CPC) de 1973 é impugnável por meio de ação anulatória", conforme noticiado no Informativo 916, do STF sobre a AR 2440 AgR/DF, Ministro Relator Ricardo Lewandowski, julgada em 19.09.2018.

77 GONÇALVES, Tiago Figueiredo; MAZZEI, Rodrigo Reis. Primeiras linhas sobre a disciplina da ação rescisória no CPC/2015. Revista Forense (Impresso), 2015, v. 421, p. 194.

${ }^{78}$ Art. 966. A decisão de mérito, transitada em julgado, pode ser rescindida quando: [...]; II - for proferida por juiz impedido ou por juízo absolutamente incompetente; [...].

${ }_{79}$ ABELHA, Op. Cit., p. 150.

${ }^{80}$ WAMBIER, Luiz Rodrigues; ARRUDA ALVIM WAMBIER, Teresa; MEDINA, José Miguel Garcia. Breves Comentários à nova sistemática processual civil 2. São Paulo: Revista dos Tribunais, 2006, p.171.
} 
Após essa breve reflexão sobre o objeto deste estudo, podemos expor as seguintes conclusões:

i) o art. 725, VIII do CPC/2015 disciplina o procedimento para a decisão homologatória de autocomposição extrajudicial (art. 515, III, do CPC/2015), mas não se limita a ele, pois nada impede que se profira decisão homologatória de autocomposição extrajudicial que não resulte em título executivo judicial;

ii) a decisão homologatória de autocomposição extrajudicial contempla hipótese diversa da decisão que homologa autocomposição judicial;

iii) é juridicamente possível a submissão de título executivo extrajudicial à decisão homologatória judicial (art. 785 do CPC/2015);

iv) o interesse na homologação da autocomposição extrajudicial advém da necessidade de se conferir maior segurança jurídica à avença e assegura uma execução mais efetiva;

v) o rito procedimental que resulta na decisão homologatória de autocomposição extrajudicial é aquele que disciplina as normas gerais da jurisdição voluntária;

vi) a doutrina, em geral, apresenta três significados à expressão "qualquer natureza" contida tanto no art. 725, VIII como no art. 515, III do CPC/2015: um relacionado à disponibilidade do direito; um segundo que diria respeito à obrigação instituída pela autocomposição; e um terceiro equivalente a "qualquer matéria".

vii) quanto ao primeiro significado, concluímos que a autocomposição extrajudicial pode recair tanto sobre direitos disponíveis quanto indisponíveis;

viii) no tocante ao segundo significado, interpretamos que a autocomposição pode envolver qualquer modalidade de cumprimento da obrigação pactuada;

ix) sobre o terceiro significado ("qualquer natureza" = "qualquer matéria"), expusemos que a autocomposição feita fora do processo pelas partes pode envolver qualquer matéria ou valor, desde que respeitada a competência do juízo responsável por homologála;

x) em obediência às premissas lançadas, a autocomposição extrajudicial que contenha várias cláusulas, de forma que algumas sejam de competência para apreciação da Justiça Comum, enquanto outras sejam de competência para análise pela Justiça do Trabalho, não pode ser homologada em sua completude, seja pelo Juiz de Direito, seja pelo 
Juiz do Trabalho. Excepcionalmente, a Constituição Federal delega competência juslaboral ao Juiz de Direito, consoante norma construída a partir da interpretação do seu art. 112;

xi) é cabível a ação rescisória para rescindir decisão homologatória de autocomposição extrajudicial proferida por juízo absolutamente incompetente (art. 966, II, do CPC/2015);

xii) a declaração de incompetência do juízo não retira eventual eficácia executiva do título executivo extrajudicial, caso preenchidos os requisitos exigidos pelo art. 784 do $\mathrm{CPC} / 2015$.

\section{REFERÊNCIAS}

ABELHA, Marcelo. Manual de execução civil. 6. ed. Rio de Janeiro: Forense, 2016.

ACORDO trabalhista entre membros de família encerra processo no TRT-ES. 2018. Disponível em:

<http://www.trtes.jus.br/principal/comunicacao/noticias/conteudo/1941-acordotrabalhista-entre-membros-de-familia-encerra-processo-no-trt-es>. Acesso em: 16.12.2020.

ARRUDA ALVIM, Teresa. Nulidades do processo e da sentença. 8. ed. São Paulo: Revista dos Tribunais, 2017.

ARRUDA ALVIM WAMBIER, Teresa et. al. (coord.). Primeiros comentários ao novo código de processo civil: artigo por artigo. 2. ed. rev., atual. e ampl. São Paulo: Revista dos Tribunais, 2016.

ASSIS, Araken de. Manual da execução. 19 ed. São Paulo: Revista dos Tribunais, 2017.

BERMUDES, Sérgio. CPC de 2015: inovações. 1. ed. Rio de Janeiro: LMJ Mundo Jurídico, 2018.

BONICIO, Marcelo José Magalhães. Comentários ao art. 475-N, V, do CPC/73. In: ARMELIN, Donaldo et. al. Comentários à execução civil: título judicial e extrajudicial (artigo por artigo) - de acordo com as Leis n. 11.232/2005 e 11.382/2006. São Paulo: Saraiva, 2008.

BRASIL. Constituição da República Federativa do Brasil de 1988. Disponível em: http://www.planalto.gov.br/ccivil_03/constituicao/constituicao.htm. Acesso em: 16 dez. 2020. 
Lei $\mathrm{n}^{\circ}$ 5.869, de 11 de janeiro de 1973. Institui o Código de Processo Civil.

Disponível em: http://www.planalto.gov.br/ccivil_03/leis/15869impressao.htm. Acesso em: 16 dez. 2020.

. Lei $\mathrm{n}^{\circ} 7.244$, de 7 de novembro de 1984. Dispõe sobre a criação e o funcionamento

do Juizado Especial de Pequenas Causas. Disponível em: http://www.planalto.gov.br/ccivil_03/leis/1980-1988/17244.htm. Acesso em: 16 dez. 2020.

. Lei $\mathrm{n}^{\circ}$ 9.099, de 26 de setembro de 1995. Dispõe sobre os Juizados Especiais Cíveis e Criminais e dá outras providências. Disponível em: http://www.planalto.gov.br/ccivil_03/leis/19099.htm. Acesso em: 16 dez. 2020. . Lei $\mathrm{n}^{\circ} 11.232$, de 22 de dezembro de 2005. Altera a Lei $\mathrm{n}^{\circ} 5.869$, de 11 de janeiro de 1973 - Código de Processo Civil, para estabelecer a fase de cumprimento das sentenças no processo de conhecimento e revogar dispositivos relativos à execução fundada em título judicial, e dá outras providências. Disponível em: http://www.planalto.gov.br/ccivil_03/_Ato2004-2006/2005/Lei/L11232.htm.

Acesso em: 16 dez. 2020.

. Lei no 13.105, de 16 de março de 2015. Código de Processo Civil. Disponível em: http://www.planalto.gov.br/ccivil_03/_ato2015-2018/2015/lei/113105.htm. Acesso em: 16 dez. 2020.

${ }^{1}$ DIDIER JR., Fredie et al. Curso de Direito Processual Civil: Execução. 6. ed. Salvador: Juspodivm, 2014, vol. 5, p. 170.

BUENO, Cassio Scarpinella. A nova etapa da reforma do Código de Processo Civil: comentários sistemáticos às Leis n. 11.187, de 19-10-2005, e 11.232, de 22-12-2005. 2. ed. São Paulo: Saraiva, 2006. V. 1.

. Curso sistematizado de direito processual civil: procedimentos especiais do Código de Processo Civil. Juizados Especiais, vol. 2, tomo II. 2. ed. São Paulo: Saraiva, 2013.

CALMON, Petrônio. Fundamentos da mediação e da conciliação. 2. ed. Brasília/DF: Gazeta Jurídica, 2013.

CHIMENTI, Ricardo Cunha. Teoria e prática dos juizados especiais cíveis. 2. ed. São Paulo: Saraiva, 1999.

COSTA, Hélio Martins. Lei dos juizados especiais cíveis anotada e sua interpretação jurisprudencial. Belo Horizonte: Del Rey, 1998. 
CRUZ, Aloysio Álvares. A transação, a conciliação e o acordo extrajudicial. Revista de Jurisprudência do Tribunal de Justiça de São Paulo. Vol. 109 - ano 21 - $6^{\circ}$ bimestre, novembro e dezembro de 1987.

DIDIER JR., Fredie. Curso de direito processual civil: introdução ao direito processual civil, parte geral e processo de conhecimento. 19. ed. Salvador: Jus Podivm, 2017. et al. Curso de Direito Processual Civil: Execução. 6. ed. Salvador: Juspodivm, 2014, vol. 5.

DINAMARCO, Cândido Rangel. Execução civil. 7. ed. São Paulo: Malheiros, 2000. Instituições de Direitos Processual Civil. 3. ed. São Paulo: Malheiros, 2009, vol. 4. FIGUEIRA JÚNIOR, Joel Dias; LOPES, Mauricio Antônio Ribeiro. Comentários à lei dos juizados especiais cíveis e criminais: Lei 9.099, de 26.09.1995. 3 ed. São Paulo: Revista dos Tribunais, 2000.

FUX, Luiz. $O$ novo processo de execução (cumprimento da sentença e a execução extrajudicial). Rio de Janeiro: Forense.

GONÇALVES, Tiago Figueiredo; MAZZEI, Rodrigo Reis. Primeiras linhas sobre a disciplina da ação rescisória no CPC/2015. Revista Forense (Impresso), 2015, v. 421, p. 191-213.

GRECO, Leonardo. Jurisdição Voluntária Moderna. São Paulo: Dialética, 2003. . Comentários ao art. 725. In: ARRUDA ALVIM WAMBIER, Teresa et al. (coord.). Breves comentários ao novo código de processo civil. 3. ed. São Paulo: Revista dos Tribunais, 2016.

LEITE, Maria Auxiliadora Sobral. Juizados Especiais Cíveis: processo de conhecimento. In: FARIAS, Cristiano Chaves de; DIDIER JR., Fredie (coord.). Procedimentos especiais cíveis: legislação extravagante. São Paulo: Saraiva, 2003.

MARCATO, Antonio Carlos (coord.). Código de processo civil interpretado. 3. Ed. São Paulo: Atlas, 2008. Procedimentos especiais. 17. ed. São Paulo: Atlas, 2017.

MAIA, Daniel Netto. Da possibilidade e utilidade da homologação em juízo de acordos extrajudiciais independentemente da prévia instauração de processo judicial. Revista Jus Navigandi, ISSN 1518-4862, Teresina, ano 18, n. 3733, 20 set. 2013. Disponível em: https://jus.com.br/artigos/25347. Acesso em: 16 dez. 2020. 
MARINONI, Luiz Guilherme; ARENHART, Sérgio Cruz; MITIDIERO, Daniel. Novo curso de processo civil: tutela dos direitos mediante procedimento comum, volume 2. 3 ed. São Paulo: Revista dos Tribunais, 2017.

MARQUES, José Frederico. Ensaio sobre a jurisdição voluntária. Campinas: Millennium, 2000 .

MELO, José Maria de; TEÓFILO NETO, Mário Parente. Lei dos juizados especiais: comentada. $1^{\circ}$ ed., $2^{a}$ tir. Curitiba: Juruá, 1997.

MONTENEGRO FILHO, Misael. Código de processo civil comentado e interpretado. São Paulo: Atlas, 2008.

MOREIRA, Wander Paulo Marotta. Juizados especiais cíveis. Belo Horizonte: Del Rey, 1996.

NEGRÃO, Theotonio; GOUVÊA, José Roberto Ferreira; BONDIOLI, Luiz Guilherme Aidar (colaborador). Código de Processo Civil e legislação processual em vigor. 40. ed. São Paulo: Saraiva, 2008,p. 1645, nota 2 referente ao art. 57 da Lei 9.099/95.

NEVES, Daniel Amorim Assumpção. Manual de direito processual civil. Salvador: Juspodivm, 2017. V. único.

PRATA, Edson. Jurisdição Voluntária. São Paulo: Livraria e Editora Universitária de Direito Ltda, 1979.

SANTOS, Ernane Fidélis dos. As reformas de 2005 e 2006 do Código de Processo Civil: execução dos títulos judiciais e agravo de instrumento. 2. ed. São Paulo: Saraiva, 2006.

SHIMURA, Sérgio. Comentários ao art. 515. In: ARRUDA ALVIM WAMBIER, Teresa et al. (coord.). Breves comentários ao novo código de processo civil. 3. ed. São Paulo: Revista dos Tribunais, 2016.

SILVA, Jorge Alberto Quadros de Carvalho. Lei dos juizados especiais cíveis anotada: (doutrina e jurisprudência dos 27 Estados da Federação). 2. ed. São Paulo: Saraiva, 2001 .

TALAMINI, Eduardo. Coisa julgada e sua revisão. São Paulo: Revista dos Tribunais, 2005.

TARTUCE, Fernanda. Lei no 11.232/05, art. 475-N, inciso IV (sic): acordo extrajudicial de qualquer natureza homologado em juízo como título executivo judicial. Revista EPD - Escola Paulista de Direito. Ano 2, n. 3 (out./nov. 2006), 2006. 
THEODORO JR., Humberto. Curso de Direito Processual Civil - Procedimento Especiais - vol. II. 50 a ed. Rio de Janeiro: Forense, 2016.

TOURINHO NETO, Fernando da Costa; FIGUEIRA JÚNIOR, Joel Dias. Juizados Especiais Estaduais Cíveis e Criminais: Comentários à Lei 9.099/1995. 5.ed. São Paulo: Revista dos Tribunais, 2007, p. 363)

VENTURI, Elton. Transação de direitos indisponíveis? Revista de Processo, vol. 251 (janeiro de 2016).

WAGNER JÚNIOR, Luiz Guilherme da Costa. A sentença homologatória de acordo extrajudicial e sua executoriedade. In: MEDINA, José Miguel Garcia et. al. (coord.). Os poderes do juiz e o controle das decisões judiciais. São Paulo: Revista dos Tribunais, 2008.

WAMBIER, Luiz Rodrigues; ARRUDA ALVIM WAMBIER, Teresa; MEDINA, José Miguel Garcia. Breves comentários à nova sistemática processual civil 2. São Paulo: Revista dos Tribunais, 2006.

WATANABE, Kazuo [et al.]. Juizado especial de pequenas causas: Lei n. 7.244, de 7 de novembro de 1984. São Paulo: Revista dos Tribunais, 1985.

ZAVASCKI, Teoria Albino. Comentários ao código de processo civil: do processo de execução, arts. 566 a 645. 2. ed . São Paulo: Revista dos Tribunais, 2003. 